\title{
Polyamines in human health
}

\author{
B Y HEATHER M. WALLACE
}

Department of Medicine \& Therapeutics and Biomedical Sciences, University of Aberdeen, Polwarth Building, Foresterhill, Aberdeen AB9 2ZD

\section{Les polyamines dans la santé de l'homme}

\section{RÉSUMÉ}

Les polyamines sont essentielles pour la croissance de toutes les cellules vivantes. Elles sont synthétisées de novo par une série de réactions de décarboxylation et d'aminopropyl transférase, ou sont absorbées de l'alimentation et de la flore intestinale. Il existe une relation positive entre les taux de la croissance des cellules et le contenu intracellulaire des polyamines. En général, le contenu en polyamines est élevé dans les cellules qui grandissent rapidement, et faible dans les cellules en repos. On trouve couramment des concentrations de polyamines élevées dans les cellules et tissus de cancer, mais la fonction précise des polyamines dans les cellules cancéreuses n'est pas claire. Le contenu en polyamines dans le système urinaire est également augmenté dans les maladies malignes, et ceci peut donner des informations sur la réponse des patients individuels au traitement, bien qu'il ne puisse pas servir à l'établissement du diagnostic. La voie de la biosynthèse des polyamines est une cible pour des agents anticancéreux spécifiquement conçus, le mieux utilisé d'entre eux étant l'a-difluorométhylornithine (DFMO) qui inhibe la décarboxylase de l'ornithine ( $E C 4.1 .1 .17$ ), la première enzyme limitante dans cette voie. La DFMO est un agent antiproliférant in vitro mais ses effets sont plus cytostatiques que cytotoxiques. Chez l'homme, l'utilisation de la DFMO en monothérapie comme agent anticancéreux a été décevante, mais, parce qu'il n'est pas toxique, le DFMO a été combiné avec un certain nombre d'autres médicaments parmi lesquels le nitrosourée, le méthylglyoxal bis(guanylhydrazone) (MGBG) et la cyclosporine $\mathrm{A}$, produisant une élévation des effets antitumoraux. On a synthétisé de nouveaux inhibiteurs compétitifs de la voie vers la décarboxylase d'adénosylméthionine-S et basés et sur la structure du MGBG. Ceux-ci améliorent significativement l'activité antitumorale sur la DFMO ou son parent le MGBG. De plus, ces nouveaux inhibiteurs de la décarboxylase d'adénosylméthionine-S ( $E C$ 4.1.1.50) ont montré une toxicité moins importante que le MGBG. Une autre stratégie pour l'élimination des polyamines dans les cellules est l'utilisation des analogues des polyamines, très notoirement les dérivés bis(éthyls). Ces analogues agissent de plusieurs manières: inhibition de la biosynthèse en retour, induction d'acétyltransférase $\mathrm{N}^{1}$ spermidine/spermine, et couplage aux sites intracellulaires. Ces analogues sont captés par le transporteur des polyamines mais ne remplacent pas les polyamines en terme de fonction. Une stratégie alternative vise à éliminer totalement les polyamines en combinant les inhibiteurs de la biosynthèse des polyamines et les reconvertir avec des antibiotiques et un régime sans polyamines. Là encore, le succès a été obtenu chez des modèles animaux. La DFMO peut également être un agent chimiopréventif chez des patients qui ont un risque élevé de développer un cancer. On peut soutenir que l'utilisation la plus bénéfique des inhibiteurs des poly- 
amines comme médicament efficace chez l'homme est dans le traitement des infections causées par Trypanosoma brucei spp. Les inhibiteurs de la DFMO et de la décarboxylase d'adénosylméthionine-S peuvent guérir des infections chez les modèles animaux, dans le bétail et chez l'homme. Un certain succès a également obtenu dans le traitement d'autres maladies parasitaires telles que la Leishmaniose et le paludisme, et ceci est à l'évidence un domaine où il faudra développer davantage les antimétabolites des polyamines.

The polyamines, spermidine and spermine, are naturally-occurring aliphatic amines which were first isolated as 'three-sided' crystals from human semen in 1678 by Antonie van Leewenhoek (for review, see Cohen, 1971). The base was named 'spermin' 200 years later, and in the 1920s Dudley et al. (1927) achieved the first chemical synthesis of the tetra-amine now known as spermine (Fig. 1). The diamine, putrescine (Fig. 1), which derives its name from the large quantities found in putrefying flesh, was isolated from Vibrio cholera in 1889 and, as the precursor of spermidine and spermine, is usually considered with these polyamines for convenience.

Polyamines are found in all living organisms. They occur in bacteria and fungi (for review, see Tabor \& Tabor, 1985), in plants (Evans \& Malmberg, 1989) and in viruses as well as in mammalian cells (Pegg, 1986). The distribution of polyamines differs between species and in mammalian cells between tissues. For example, bacteria contain mainly putrescine and spermidine, while in mammalian cells spermidine and spermine generally predominate, with putrescine being found in much lower amounts. In man, the greatest concentrations of polyamines are found in the prostate gland, although high concentrations are also found in the liver and pancreas (for review, see Cohen, 1971). In terms of intracellular distribution, studies have been complicated by the redistribution of polyamines in aqueous environments, but McCormick (1978) used cytochalsin B to enucleate cells and showed spermidine and spermine to be concentrated in the nucleus. A similar association of polyamines with the nucleus was suggested by Cooper et al. (1976) who showed that leukocytes, which are nucleated cells, had a polyamine content several orders of magnitude higher than erythrocytes, which are enucleated cells. In addition to the free polyamines (Fig. 1), monoacetyl polyamine derivatives are found in mammalian cells and in some bacteria (Dubin \& Rosenthal, 1960; Tabor, 1968). Conjugates of spermidine and spermine with glutathione have been found in Escherichia coli under conditions of stress (Tabor \& Tabor, 1970) and in Trypanosomes, where

Putrescine

$$
\mathrm{H}_{3}{ }^{+} \mathbf{N}\left(\mathrm{CH}_{2}\right)_{4} \mathrm{NH}_{3}^{+}
$$

Spermidine

$$
\mathrm{H}_{3}^{+} \mathbf{N}\left(\mathrm{CH}_{2}\right)_{4} \mathrm{NH}_{2}^{+}\left(\mathrm{CH}_{2}\right)_{3} \mathrm{NH}^{+}
$$

Spermine

$$
\mathrm{H}_{3}{ }^{+} \mathrm{N}\left(\mathrm{CH}_{2}\right)_{3} \mathrm{NH}_{2}{ }^{+}\left(\mathrm{CH}_{2}\right)_{4} \mathrm{NH}_{2}^{+}\left(\mathrm{CH}_{2}\right)_{3} \mathrm{NH}_{3}{ }^{+}
$$

Fig. 1. The structure of the naturally-occurring polyamines. 
glutathionylspermidine is a precursor of trypanothione, the protozoan equivalent of glutathione (for review, see Fairlamb \& Cerami, 1992).

In terms of function, polyamines are believed to be essential for cell growth and differentiation since cells lacking polyamines, either because of mutation or inhibition of de novo biosynthesis, do not grow without addition of exogenous polyamines. Polyamine deprivation can be achieved either by mutation of the biosynthetic pathway, as in the spe mutants in Saccharomyces cerevisiae (Tabor, 1981), or by prevention of biosynthesis by treatment with agents such as $\alpha$-difluoromethylornithine (DFMO; eflornithine, Ornidyl). Two families of Archaea, Methanobacteriales and Halobacteriales, however, do appear to grow without any measurable polyamine content (Marton \& Pegg, 1995).

\section{SOURCES OF POLYAMINES}

In mammalian cells there are three possible sources of polyamines: biosynthesis from constituent amino acids, uptake of preformed polyamines from the diet and a supply, again of preformed polyamines, from intestinal flora.

Polyamines are synthesized de novo in mammalian cells from two amino acids, L-ornithine and L-methionine (Fig. 2). In the initial reaction ornithine is decarboxylated by ornithine decarboxylase $(E C 4$.1.1.17; ODC) to form putrescine. Methionine reacts with ATP to produce S-adenosylmethionine (SAM) which is an intermediate in methylation reactions within the cell. SAM is then activated in a second decarboxylation reaction catalysed by S-adenosylmethionine decarboxylase (EC 4.1.1.50; AdoMetDC) to form decarboxy SAM. This decarboxy intermediate then donates an aminopropyl moiety to putrescine to produce spermidine (catalysed by spermidine synthase; $E C$ 2.5.1.16) and finally a second decarboxy SAM molecule combines with spermidine to form spermine (catalysed by spermine synthase; $E C$ 2.5.1.22). This pathway is essentially irreversible with the only known fate of decarboxy SAM being the synthesis of the higher polyamines.

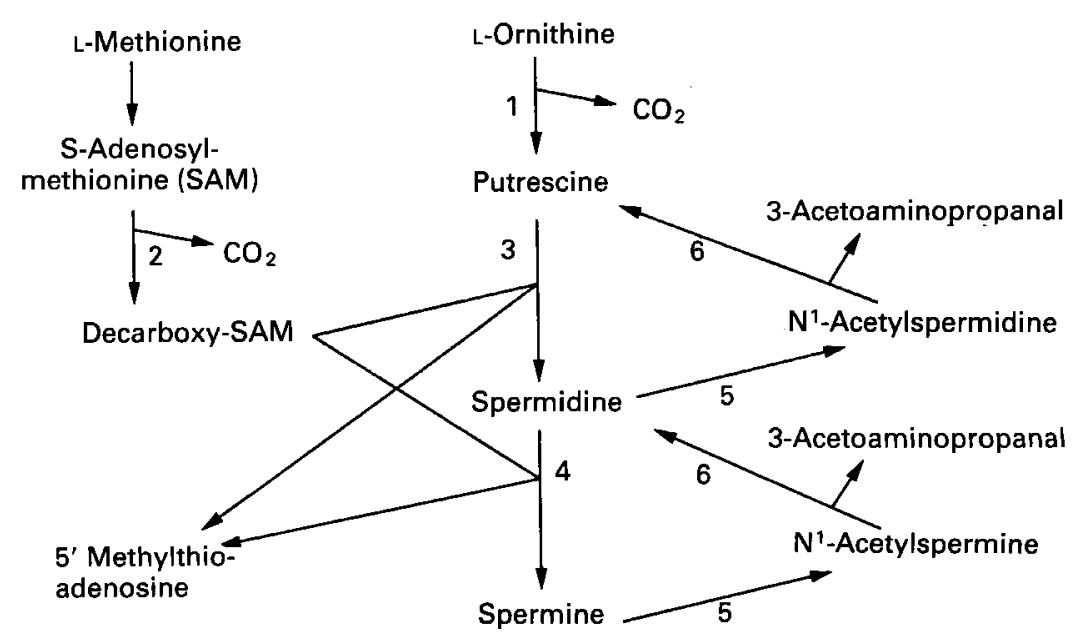

Fig. 2. Polyamine metabolic pathways in mammalian cells. 1 , Ornithine decarboxylase $(E C$ 4.1.1.17); 2 , S-adenosylmethionine decarboxylase $(E C 4.1 .1 .50) ; 3$, spermidine synthase $(E C 2.5 .1 .16) ; 4$, spermine synthase $(E C 2.5 .1 .22) ; 5$, spermidine/spermine $\mathrm{N}^{1}$-acetyltransferase; 6 , polyamine oxidase. 


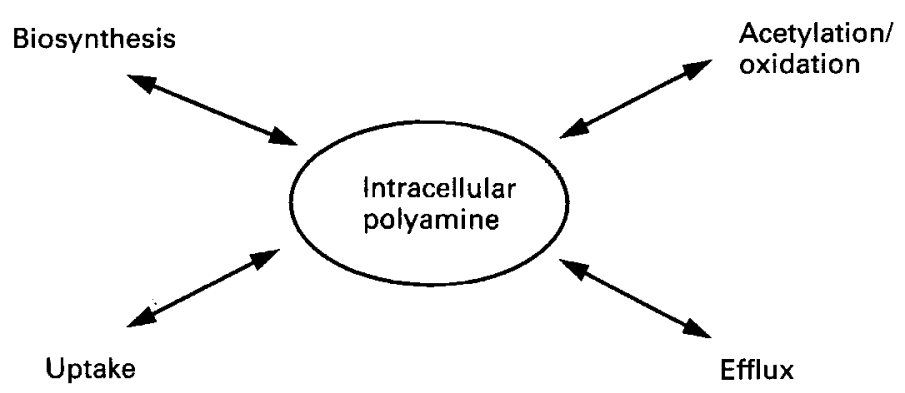

Fig. 3. Regulation of intracellular polyamine content.

Conversion of spermine and spermidine back to putrescine occurs via a separate pathway, the retroconversion pathway (Seiler et al. 1980). Spermine is monoacetylated in a reaction catalysed by the enzyme, spermidine/spermine $\mathrm{N}^{1}$-acetyltransferase $\left(\mathrm{N}^{1}\right.$-SAT). This acetyl polyamine is then the preferred substrate for the FAD-containing polyamine oxidase (PAO; Seiler et al. 1981) which produces spermidine and 3acetoaminopropanal (Fig. 2). Two similar reactions convert spermidine to putrescine. Spermidine is an asymmetric molecule and the acetyltransferase only acetylates on the aminopropyl moiety of spermidine (Wallace \& Coleman, 1990). Thus, ornithine can be converted to spermine and then back to putrescine via a set of six enzyme reactions each of which is subject to regulation by the substrate and/or product.

Polyamines are also available from the diet (for review, see Bardocz, 1993). Large amounts of polyamines occur in foodstuffs such as cheese, green vegetables and oranges. Interestingly, significant quantities of polyamines have been found in human milk (Romain et al. 1992) where, it has been suggested, polyamines may play a role in protecting the newborn from food allergies. Bottle-fed babies, who are exposed to significantly lower polyamine concentrations in infant formulas, are more susceptible to food allergy:

The third important source of polyamines in man is the gut flora (Dowling et al. 1992). Intestinal microbes produce their own polyamines from ornithine and lysine, including cadaverine (1,5-diaminopentane), and these are available to the host either through active excretion of the polyamines or as the result of leakage from dead or dying organisms.

At present it is not clear what contribution each of these sources makes to the overall polyamine content of mammalian cells, but increasing evidence suggests that the last two sources make a significant contribution to polyamine homeostasis in man.

\section{POLYAMINE HOMEOSTASIS}

The polyamine content of a cell is regulated according to need, with rapidly-growing cells requiring high polyamine contents and quiescent cells a low content of polyamine growth factors. Intracellular polyamine concentrations are a balance between biosynthesis and transport into the cell (uptake) on the one hand and catabolism and transport out of the cell (efflux) on the other (Fig. 3). There is a coordinated regulation between these pathways in that when growth is initiated by, for example, the addition of fresh serum to mammalian cells in culture, biosynthesis and uptake are increased while efflux and 
acetylation and/or oxidation are down-regulated (Wallace \& Keir, 1981). The opposite occurs when growth is limited by removal of growth factors or deprivation of an essential nutrient such as serum (Melvin \& Keir, 1978: Melvin et al. 1980). The signals which initiate the up- and down-regulation of these pathways remain unclear, although recent studies have suggested there might be role for $\mathrm{Ca}^{2+}$, at least in the regulation of $\mathrm{N}^{1}$-SAT (Quick \& Wallace, 1993).

There are three points of regulation in polyamine metabolism: two in the biosynthetic pathway, ODC and AdoMetDC, and one in the retroconversion pathway, $\mathrm{N}^{1}$-SAT. These enzymes share several key features as outlined in Table 1. The two most obvious similarities between the enzymes are their inducibility and their rapid turnover rates (for reviews, see Pegg, 1986, 1988). The latter is thought to be a key feature of regulatory enzymes. It enables a fast response to stimuli, but in the case of two of the polyamine enzymes, ODC and AdoMetDC, inhibitors of the reactions have also been found to stabilize the enzymes against proteolytic degradation compounding the difficulty in attempts to understand the role of polyamines through their depletion from cells. ODC and AdoMetDC are increased 5-60-fold by stimuli which increase the rate of cell growth. Increases in activity occur early in the response, leading to the suggestion that ODC is an early gene in terms of cell growth. In the cell cycle, ir reases in ODC occur before $\mathrm{S}$-phase suggesting a role for the polyamines in DNA replication (Heby \& Anderson, 1980).

$\mathrm{N}^{1}$-SAT is also inducible, but usually by agents which inhibit cell growth or are cytotoxic (Wallace \& Quick, 1994). The extent of induction of $\mathrm{N}^{1}$-SAT varies with the inducer and with the cell line. For example, in melanoma cells the greater the induction of $\mathrm{N}^{1}$-SAT by bis(ethyl)spermine, a synthetic polyamine analogue, the greater the inhibition of cell growth (Porter et al. 1991). The induction of $\mathrm{N}^{1}$-SAT activity is many thousand fold in the most sensitive cell lines. Another analogue of the polyamines, methylglyoxal bis(guanylhydrazone) (MGBG), also induces the enzyme from 5-400-fold depending on the type of cell used. Both the bis(ethyl) analogues and MGBG stabilize

Table 1. Regulatory features of the rate-limiting enzymes in polyamine metabolism

\begin{tabular}{ll}
\hline \hline Ornithine decarboxylase (EC 4.1.1.17) & Highly inducible \\
& Rapid turnover (half-life approximately 10-20 min) \\
& PEST sequence \\
Antizyme & Transcriptional and/or post-transcriptional regulation \\
& Translational and/or post-translational regulation \\
& Post-translational modification \\
S-adenosylmethionine decarboxylase ( $E C$ 4.1.1.50) & Highly inducible \\
& Rapid turnover (half-life approximately 40-60 min) \\
& PEST sequence \\
& Transcriptional and/or post-transcriptional regulation \\
& Translational and/or post-translational regulation \\
& Highly inducible \\
Spermidine/spermine $\mathrm{N}^{1}$-acetyltransferase & Rapid turnover (half-life approximately 10-40 min) \\
& Transcriptional regulation \\
\hline
\end{tabular}

PEST, proline-glutamate-serine-threonine. 
the enzyme against proteolytic degradation (Wallace et al. 1988; Libby et al. 1992), which contributes to the increased activity found in the presence of these agents. It is not clear how great a contribution this stabilization makes to the increase in enzyme activity, but a recent paper from Pegg's laboratory (Parry et al. 1995) has suggested that stabilization by bis(ethyl)spermine can only contribute 40 -fold to the overall 380 -fold increase in $\mathrm{N}^{1}$-SAT activity in transfected COS-7 cells.

ODC and AdoMetDC also contain PEST (proline-glutamate-serine-threonine) sequences, which are believed to be signals contained in the carboxy terminal end of the protein which target the enzyme for degradation (Rogers et al. 1986). $\mathrm{N}^{1}$-SAT does not contain such a sequence and little is yet known about the degradation of this protein. Other details of how the individual enzymes are regulated can be found in comprehensive reviews by Heby \& Persson (1990), Janne et al. (1991), Pegg (1986) and Casero \& Pegg (1993).

\section{POLYAMINES IN HUMAN DISEASE}

\section{Cancer}

In view of the relationship between polyamines and cell growth, much research effort was directed to examining the possible involvement of polyamines in diseases where disturbance in growth regulation was part of the disease aetiology (for review, see Pegg, 1988). Research focused on cancer, and in the early 1970s Diane Russell (Russell et al. 1971) reported that patients with a variety of malignant conditions excreted significantly higher amounts of polyamines in their urine than did normal individuals. This led to a great flurry of activity examining the possibility that polyamines in body fluids may be biological markers of malignancy (for reviews, see Janne et al. 1978; Pegg, 1988). Unfortunately, as a marker, polyamines, particularly urinary polyamines, were nonspecific with false positives being observed in patients with gastrointestinal diseases (Loser et al. 1990) and during pregnancy (Russell et al. 1971).

The possibility that urinary polyamine measurements can monitor the response of an individual patient to therapy still merits some consideration. A sharp increase in urinary polyamine output is a normal response to the initial treatment, be it surgery, radio- or chemotherapy (Russell et al. 1975; Durie et al. 1977). In the responding patient, urinary polyamine concentrations then fall to within the normal range where they remain while that patient is in remission. Patients with a recurrent tumour or metastatic disease, on the other hand, show increased polyamine excretion and, thus, the response of an individual can be monitored.

Tumour tissue was also found to contain significantly higher concentrations of polyamines than normal tissue. In colo-rectal-cancer tissue, for example, there were increases of about 3-4-fold in all three free polyamines when compared with normal tissue (Kingsnorth et al. 1984a). Similar results were observed in breast-cancer tissue (Kingsnorth et al. 1984b) but in the breast-tumour tissue there were, in addition, significant concentrations of monoacetylated polyamines (Kingsnorth \& Wallace, 1985) which were absent from both normal and benign tumour tissue $(\mathbf{H}$. M. Wallace and A. N. Kingsnorth, unpublished results). Attempts to link polyamine content of the tumour tissue to disease progression in colo-rectal cancer proved negative with no relationship obvious between Dukes' stage, histology, tumour site or liver metastasis and the polyamine content (Kingsnorth et al. 1984a). In contrast, in breast cancer there are 
Table 2. Breast cancer and polyamines: summary

\begin{tabular}{llc}
\hline \hline Diagnostic tool & Polyamine correlation & Statistical significance: $P<$ \\
\hline Histological grade & Highest in grade III & 0.05 \\
Oestrogen-receptor status & Highest in ER, negative & 0.05 \\
Tumour size & Highest content in largest tumours & 0.05 \\
Tumour recurrence & Highest content in recurring tumours & $0 \cdot 02$ \\
Node status & Highest in node, positive & NS \\
\hline \hline
\end{tabular}

ER, oestrogen receptor.

positive correlations between tumour size, histological grade, oestrogen-receptor status and tumour recurrence and the polyamine content of the tumour tissue. These results are summarized in Table 2 (Kingsnorth et al. 1984b). In every case the more aggressive the tumour the higher the polyamine content. Thus, useful information can be gained about the disease from a knowledge of the tumour-tissue polyamine content.

As a result of the high polyamine content of cancer cells and the relationship between polyamines and cell growth, the enzymes of the biosynthetic pathway became a target for anti-cancer drug design. In the late 1970s, Phillipe Bey and colleagues (Metcalf et al. 1978) synthesized DFMO, a suicide or enzyme-activated inhibitor of ODC. Since then, DFMO has been one of the most-used compounds in polyamine research and its availability has done much to help our understanding of the role of polyamines in cells in both health and disease.

In vitro, DFMO was very successful as an anti-proliferative agent. It inhibited the growth of a range of tumour cells in culture, and it depleted putrescine and spermidine concentrations to below the limit of detection in many cells. However, it had little effect on the intracellular content of spermine, possibly due to the compensatory increase in AdoMetDC and accumulation of decarboxy SAM (for review, see Marton \& Pegg, 1995). Unfortunately, the effects of DFMO on cells were cytostatic and not cytotoxic as the original strategy had predicted. In terms of mechanism of action, DFMO is decarboxylated by ODC and the resultant reactive intermediate covalently binds to the active site of the enzyme and, thus, inactivates it irreversibly (Metcalf et al. 1978). ODC is rapidly turned over in mammalian cells and so high concentrations of DFMO must be maintained. DFMO enters cells by diffusion and, therefore, uptake is slow; it is also rapidly cleared from the body by excretion, which means it is not an ideal drug for therapeutic use.

Despite the promising results in vitro, DFMO as a single agent has met with only marginal clinical success (for review, see Marton \& Pegg, 1995). One of the major reasons for this is the compensatory increase in the polyamine uptake transporters which occurs on treatment with DFMO (Alhonen-Hongisto et al. 1980; Seiler et al. 1990). Exogenous polyamines, which may be derived from the diet, gut flora or released from cells either normally from healthy cells (Wallace \& Keir, 1981) or pathologically from damaged or dying cells, are accumulated by cells when the normal pathway of endogenous biosynthesis has been blocked. The net effect of this is, therefore, no change in the overall polyamine content.

\section{DFMO in combination with other agents}

In man, DFMO is non-toxic, with the limited side effects being dose related and reversed 
Table 3. Strategy for complete polyamine depletion

\begin{tabular}{ll}
\hline \hline DFMO & $\begin{array}{l}\text { To prevent polyamine synthesis } \\
\text { MDL 72527 }\end{array}$ \\
Polyamine-free diet & $\begin{array}{c}\text { Inhitor of PAO to prevent polyamine } \\
\text { To limit circulating polyamines }\end{array}$ \\
Antibiotics & $\begin{array}{c}\text { To decontaminate gut and limit circulating } \\
\text { polyamines }\end{array}$ \\
\hline
\end{tabular}

DFMO, $\alpha$-difluoromethylornithine; MDL 72527, PAO inhibitor (Marion Merrell Dow Co., Cinncinati, USA); PAO, polyamine oxidase.

on removal of the drug. This makes DFMO an ideal drug for combination with other cytotoxic agents to produce enhanced cytotoxicity. DFMO in combination with vindesine or adriamycin exhibited synergistic anti-tumour activity against a range of tumour models (Bartholeyns \& Koch-Weser, 1981). Similarly, in combination with bis(chlorethyl)nitrosourea (BCNU), DFMO produced enhanced anti-tumour activity (Marton et al. 1983; Tofilon et al. 1983). In the Roser T-cell leukaemia model in rats, DFMO in combination with the immunosuppressive agent, cyclosporin $\mathrm{A}$, produced a greater inhibition of the number of circulating leukaemic blasts than did either drug alone. However, the combination treatment did not further prolong survival nor did it affect organ infiltration by tumour cells (Smart et al. 1989). One possible reason for this could be the compensatory uptake of exogenous polyamines, since it was later discovered that the rat chow contained significant quantities of polyamines ( $G$. McLachlan and H. M. Wallace, unpublished results).

More recent strategies aim at complete depletion of intracellular polyamine content. In one method DFMO is combined with an inhibitor of the retroconversion pathway, MDL 72527 (Marion Merrell Dow Co., Cinncinati, USA), antibiotics and a polyaminefree diet (Table 3; Seiler et al. 1990; Moulinoux et al. 1991a,b; Quemener et al. 1994). The theory is that DFMO prevents de novo polyamine biosynthesis, MDL 72527 prevents polyamine recycling, the antibiotics decontaminate the gut and, therefore, decrease the availability of preformed polyamines and the diet makes no contribution to polyamine content. This strategy works well in preventing tumour formation in animal models. It has been shown that MDL 72527, the inhibitor of the retroconversion pathway, is not essential to achieve significant anti-tumour activity (Quemener et al. 1994). This is important since this drug has not yet been approved for use in man.

\section{Polyamine analogues}

A second strategy proposed by Porter (Porter et al. 1985) and Bergeron (Bergeron et al. 1988) makes use of polyamine analogues (Table 4) as potential anti-tumour agents. The analogues are a group of compounds which have been designed to be sufficiently similar to the natural polyamines to be taken up by the polyamine transporters, but which are sufficiently dissimilar to preclude their substituting for the polyamines in terms of function within the cell. This strategy too has worked well in animal models. The most successful compounds are the bis(ethyl)polyamine derivatives which are potent antineoplastic agents (Porter et al. 1985; Bergeron et al. 1988; Edwards et al. 1990). The 
Table 4. Strategy for the use of polyamine analogues in cancer

\begin{tabular}{ll}
\hline \hline Theory & To deplete all intracellular polyamines \\
Why analogues? & Taken up by cell \\
& Feedback inhibition of biosynthesis \\
& Do not substitute for polyamines in cell \\
& Super induction of $\mathrm{N}^{1}-\mathrm{SAT}$ \\
\hline
\end{tabular}

mechanism of action of these analogues is not completely clear but it has been shown that they inhibit polyamine biosynthesis, deplete polyamine pools and inhibit tumour growth (Porter et al. 1985). One interesting side effect of the bis(ethyl)analogues is that they are super-inducers of the enzyme $\mathrm{N}^{1}$-SAT. Since $\mathrm{N}^{1}$-SAT is involved in the efflux of polyamines from the cells (Wallace et al. 1985; Wallace \& Keir, 1986; Wallace, 1987; Wallace \& Coleman, 1990), the analogues increase polyamine depletion by increasing their loss from cells. Some of the polyamine analogues are currently undergoing clinical trials for use in cancer patients.

\section{Chemoprevention}

The latest use for DFMO in cancer therapy is as a chemopreventative agent. Being non-toxic, DFMO is an ideal candidate for chemoprevention. The objective is to give DFMO long-term to individuals who are at high risk of developing cancer. These may be patients who have had a previous tumour or individuals who may genetically be at high risk of tumour development. It is being evaluated in animal models where some success has been achieved (Kelloff et al. 1994) and at present there are a number of phase I clinical trials attempting to find a suitable dose and schedule for use in man. Of the studies to date DFMO appears to be well tolerated, with reversible ototoxicity being the major side effect.

\section{Summary}

Overall, polyamine depletion by a variety of strategies can be successful in preventing or inhibiting the growth of tumours in animal models and to some extent in man. The development of new drugs, such as the MGBG analogues synthesized by Ciba Geigy (Basel, Switzerland) which are competitive inhibitors of AdoMetDC (Regenass et al. 1992, 1994; Stanek et al. 1993a,b), will produce further improvements in cancer chemotherapy, while the use of polyamines to monitor individual patients may still be worth consideration when the recurring tumour or metastases might be occult and, therefore, difficult to detect.

\section{Polyamines and parasitic diseases}

Another area of human health where polyamine anti-metabolites have proved to be useful is in the treatment of parasitic diseases such as trypanosomiasis or sleeping sickness (African), malaria and Leishmaniasis. These are major killer diseases of the Third World which have been somewhat neglected by the pharmaceutical industry in 
favour of more profitable markets elsewhere. There have been few, if any, new drugs in this area for 25 years and those drugs that are available are inherently toxic (for review, see Fairlamb \& Cerami, 1992).

In the late 1970 s it was shown that African trypanosomes synthesized putrescine and spermidine using enzymes similar to the mammalian ODC and AdoMetDC. With the advent of DFMO it seemed logical to test the drug on the protozoans and Bacchi et al. (1980) showed that DFMO at as little as $10 \mathrm{~g} / \mathrm{l}$ in the drinking water for $3 \mathrm{~d}$ can inhibit the growth of Trypanosoma brucei brucei and cure the infection in mice. Later it was found that other trypanosomal strains such as T.b. gambiense and T.b. rhodesiense, which are pathogens in man, can also be cured by DFMO (Bacchi \& McCann, 1987; Pegg \& McCann, 1988). A series of elegant studies showed that the trypanosomal ODC did not contain a PEST sequence, the degradation signal for the enzyme, thus making it a long-lived ODC. As a long-lived enzyme, it will be much more susceptible to DFMO inhibition than the rapidly-turned-over mammalian enzyme (Ghoda et al. 1990).

More recent studies have suggested that a better target for an effective trypanocide is AdoMetDC. Currently available trypanocides such as Berenil and Pentamidine both inhibit AdoMetDC and trypanosome infections and these effects are reversed by spermidine and spermine (Bitonti et al. 1986). Therefore, specific inhibitors of AdoMetDC would be expected to be better trypanocidal agents than DFMO and, indeed, this is the case with AbeAdo, an enzyme-activated inhibitor of AdoMetDC, which is about 100 times more potent than DFMO in curing T.b. brucei infections (for review, see Marton \& Pegg, 1995). Similarly the compounds synthesized by Ciba Geigy which are analogues of MGBG are effective anti-trypanosomal agents (for review, see Bacchi \& Yarlett, 1993).

\section{CONCLUSIONS}

The polyamines are essential for the growth of cells and, therefore, strategies for anti-cancer therapy which aim to inhibit one enzyme reaction in the polyamine metabolic pathway are unlikely to be successful in achieving complete polyamine depletion since the cell has developed a range of compensatory mechanisms to counteract this; for example, the increase in uptake which occurs when intracellular biosynthesis is decreased. Therefore, combination treatments or multiple-action agents are needed. A better understanding of how the diet and micro-organisms contribute to intracellular polyamine content combined with an understanding of the regulation of polyamine transport is also necessary to provide new insights into the rational use of polyamine manipulation in therapy. The design of better inhibitors of the enzymes of polyamine metabolism is hopeful for the effective therapeutic use of polyamine antimetabolites in parasitic disease where there are biochemical differences between the host and the pathogen.

\section{REFERENCES}

Alhonen-Hongisto, L., Seppanen, P. \& Janne, J. (1980). Intracellular putrescine and spermidine deprivation induces increased uptake of the natural polyamines and methylglyoxal bis(guanylhydrazone). Biochemical Journal 192, 941-945.

Bacchi, C. J. \& McCann, P. P. (1987). Parasitic protozoa and polyamines. In Inhibition of Polyamine Metabolism: Biological Significance and Basis for New Therapies, pp. 317-344 [P. P. McCann, A. E. Pegg and A. Sjoerdsma, editors]. New York: Academic Press. 
Bacchi, C. J., Nathan, H. C., Hutner, S. H., McCann, P. P. \& Sjoerdsma, A. (1980). Polyamine metabolism: a potential therapeutic target in trypanosomes. Science 210, 332-334.

Bacchi, C. J. \& Yarlett, N. (1993). Effects of antagonists of polyamine metabolism on African trypanosomes. Acta Tropica 54, 225-236.

Bardocz, S. (1993). The role of dietary polyamines. European Journal of Clinical Nutrition 47, 683-690.

Bartholeyns, J. \& Koch-Weser, J. (1981). Effects of $\alpha$-difluoromethylornithine alone and combined with adriamycin or vindesine on L1210 leukaemia in mice, EMT6 solid tumours in mice, and solid tumours induced by injection of hepatoma tissue culture cells in rats. Cancer Research 41, 5158-5161.

Bergeron, R. J., Neims, A. H., McManis, J. S., Hawthorne, T. R., Vinson, J. R. T., Bortell, R. \& Ingeno, M. J. (1988). Synthetic polyamine analogues as antineoplastics. Journal of Medicinal Chemistry 31, 1183-1190.

Bitoni, A. J., Dumont, J. A. \& McCann, P. P. (1986). Characterisation of Trypanosoma brucei brucei S-adenosylmethionine decarboxylase and its inhibition by berenil, pentamidine and methylglyoxal bis(guanylhydrazone). Biochemical Journal 237, 685-689.

Casero, R. A. \& Pegg, A. E. (1993). Spermidine/spermine $\mathrm{N}^{\mathrm{i}}$-acetyltransferase - the turning point in polyamine metabolism. FASEB Journal 7, 653-661.

Cohen, S. S. (1971). An Introduction to the Polyamines. Engelwood Cliffs, New Jersey: Prentice-Hall Inc.

Cooper, K. D., Shukla, J. B. \& Rennert, O. (1976). Polyamine distribution in cellular compartments of blood and in ageing erythrocytes. Clinica Chimica Acta 73, 71-88.

Dowling, R. H., Folsch, U. R. \& Loser, C. (eds) (1992). In Polyamines in the Gastrointestinal Tract. Falk Symposium no. 62, pp. 389-491. Dordrecht: Kluwer Academic Publishers.

Dubin, D. T. \& Rosenthal, S. M. (1960). The acetylation of polyamines in Escherichia coli. Journal of Biological Chemistry 235, 776-782.

Dudley, H. W., Rosenheim, O. \& Starling, W. W. (1927). The constitution and synthesis of spermidine, a newly discovered base isolated from animal tissues. Biochemical Journal 21, 97-103.

Durie, B. G. M., Salmon, S. E. \& Russell, D. H. (1977). Polyamines as markers of response and disease activity in cancer chemotherapy. Cancer Research 37, 214-221.

Edwards, M. L., Prakash, N. J., Stemerick, D. M., Sunkara, S. P., Bitonti, A. J., Davis, G. F., Dumont, J. A. \& Bey, P. (1990). Polyamine analogues with antitumour activity. Journal of Medicinal Chemistry 33, 1369-1375.

Evans, P. T. \& Malmberg, R. L. (1989). Do polyamines have roles in plant development? Annual Review of Plant Physiology and Plant Molecular Biology 40, 235-269.

Fairlamb, A. H. \& Cerami, A. (1992). Metabolism and functions of trypanothione in the kinetoplastida. Annual Review of Microbiology 46, 695-729.

Ghoda, L. Y., Phillips, M. A., Bass, K. E., Wang, C. C. \& Coffino, P. (1990). Trypanosome ornithine decarboxylase is stable because it lacks sequences found in the carboxyl terminus of the mouse enzyme which target the latter for intracellular degradation. Journal of Biological Chemistry 265, 11823-11826.

Heby, O. \& Anderson, G. (1980). Polyamines and the cell cycle. In Polyamines in Biomedical Research, pp. 17-34 [J. M. Gaugas, editor]. New York: Wiley \& Sons.

Heby, O. \& Persson, L. (1990). Molecular genetics of polyamine synthesis in eukaryotic cells. Trends in the Biochemical Sciences 15, 153-158.

Janne, J., Alhonen, L. \& Leinonen, P. (1991). Polyamines: from molecular biology to clinical applications. Annals of Medicine 23, 241-259.

Janne, J., Poso, H. \& Raina, A. (1978). Polyamines in rapid growth and cancer. Biochimica et Biophysica Acta 473, 241-293.

Kelloff, G. J., Boone, C. W., Crowell, J. A., Steele, V. E., Lubet, R. \& Sigman, C. C. (1994). Chemopreventive drug development: perspectives and progress. Cancer Epidemiology Biomarkers and Prevention 3, 85-89.

Kingsnorth, A. N., Lumsden, A. B. \& Wallace, H. M. (1984a). Polyamines in colorectal cancer. British Journal of Surgery 71, 791-794.

Kingsnorth, A. N. \& Wallace, H. M. (1985). Elevation of monoacetylated polyamines in human breast cancer. European Journal of Cancer and Clinical Oncology 21, 1057-1062.

Kingsnorth, A. N., Wallace, H. M., Bundred, N. J. \& Dixon, J. M. (1984b). Polyamines in breast cancer. British Journal of Surgery 71, 352-356.

Libby, P. R., Henderson, M., Bergeron, R. J. \& Porter, C. W. (1992). Major increases in SAT activity by spermine analogues and their relationship to polyamine depletion and growth inhibition. Anticancer Research 12, 1083-1090. 
Loser, C., Folsch, U. R., Paprontny, C. \& Creutzfeldt, W. (1990). Polyamines in colorectal cancer. Evaluation of polyamine concentrations in the colon tissue, serum and urine of 50 patients with colorectal cancer. Cancer 65, 958-966.

McCormick, F. (1978). Polyamine metabolism in enucleated mouse L-cells. Journal of Cellular Physiology 93, 285-292.

Marton, L. J., Levin, V. A., Hervatin, S. J., Koch-Weser, J., McCann, P. P. \& Sjoerdsma, A. (1983). Potentiation of the antitumour therapeutic effects of 1,3 bis(2-chloroethyl)-1 nitrosourea by $\alpha$-difluoromethylornithine an ornithine decarboxylase inhibitor. Cancer Research 41, 4426-4431.

Marton, L. J. \& Pegg, A. E. (1995). Polyamines as targets for therapeutic intervention. Annual Review of Pharmacology and Toxicology 35, 55-91.

Melvin, M. A. L. \& Keir, H. M. (1978). Polyamine metabolism in BHK-21/C13 cells. Loss of spermidine from cells following transfer to serum-depleted medium. Experimental Cell Research 111, 231-236.

Melvin, M. A. L., Wallace, H. M. \& Keir, H. M. (1980). Conjugation of polyamines in mammalian cells in culture. Physiology, Chemistry and Physics 12, 431-439.

Metcalf, B. W., Bey, P., Danzin, C., Jung, M. J., Casara, J. \& Vevert, J. P. (1978). Catalytic irreversible inhibition of mammalian ornithine decarboxylase $(E C$ 4.1.1.17) by substrate and product analogues. Journal of the American Chemical Society 100, 2551-2553.

Moulinoux, J.-Ph., Quemener, V., Cipolla, B., Guille, F., Havouis, R., Martin, C., Lobel, B. \& Seiler, N. $(1991 a)$. The growth of Mat-LyLu rat prostatic adenocarcinoma can be prevented in vivo by polyamine depletion. Journal of Urology 146, 1408-1412.

Moulinoux, J.-Ph., Quemener, V. \& Kahn, N. A. (1991b). Biological significance of circulating polyamines in oncology. Cellular and Molecular Biology 37, 772-778.

Parry, L., Balna Fouce, R. \& Pegg, A. E. (1995). Post-transcriptional regulation of the content of spermidine/spermine $\mathrm{N}^{1}$-acetyltransferase by $\mathrm{N}^{1} \mathrm{~N}^{12}$-bis(ethyl)spermine. Biochemical Journal 305, 451-458.

Pegg, A. E. (1986). Recent advances in the biochemistry of the polyamines in eukaryotes. Biochemical Journal 234, 249-262.

Pegg, A. E. (1988). Polyamine metabolism and its importance in neoplastic growth as a target for chemotherapy. Cancer Research 48, 759-774.

Pegg, A. E. \& McCann, P. P. (1988). Polyamine metabolism and function in mammalian cells and protozoans. ISI Atlas of Science 20, 11-18.

Porter, C. W., Cavanaugh, P. F, J. R., Stolowich, N., Ganis, B., Kelly, E. \& Bergeron, R. J. (1985). Biological properties of $\mathrm{N}^{4}$ - and $\mathrm{N}^{1}, \mathrm{~N}^{8}$-spermidine derivatives in cultured L1210 leukaemic cells. Cancer Research 45, 2050-2057.

Porter, C. W., Ganis, B., Libby, P. R. \& Bergeron, R. J. (1991). Correlations between polyamine analogue-induced increases in spermidine/spermine $\mathrm{N}^{1}$-acetyltransferase activity, polyamine pool depletion, and growth inhibition by human melanoma cell lines. Cancer Research 51, 3715-3720.

Quemener, V., Blanchard, Y., Chamaillard, L., Havouis, R., Cipolla, B. \& Moulinoux, J.-Ph. (1994). Polyamine depletion: a new tool in cancer treatment. Anticancer Research 14, 443-448.

Quick, D. M. \& Wallace, H. M. (1993). Induction of spermidine/spermine $\mathrm{N}^{1}$-acetyltransferase in human breast carcinoma cells. Biochemical Pharmacology 46, 969-974.

Regenass, U., Caravatti, G., Mett, H., Stanek, J., Schneider, P., Muller, M., Matter, A., Vertino, P. \& Porter, C. W. (1992). New S-adenosylmethionine decarboxylase inhibitors with potent antitumour activity. Cancer Research 52, 4712-4718.

Regenass, U., Mett, H., Stanek, J., Mueller, M., Kramer, D. \& Porter, C. W. (1994). CGP 48664, a new S-adenosylmethionine decarboxylase inhibitor with broad spectrum antiproliferative and antitumour activity. Cancer Research 54, 3210-3217.

Rogers, S., Wells, R. \& Rechsteiner, M. (1986). Amino acid sequences common to rapidly degraded proteins: The PEST hypothesis. Science 234, 364-368.

Romain, N., Dandrifosse, G., Jeusette, F. \& Forget, P. (1992). Polyamine concentrations in rat milk and food, human milk and infant formulas. Paediatric Research 32, 58-63.

Russell, D. H., Levy, C. C., Schimpff, S. C. \& Hawk, I. A. (1971). Urinary polyamines in cancer patients. Cancer Research 31, 1555-1558.

Russell, D. H., Salmon, S. E. \& Durie, B. G. M. (1975). Polyamines as predictors of success and failure in cancer chemotherapy. Lancet ii, 797-799.

Seiler, N., Bolkenius, F. N. \& Knodgen, B. (1980). Acetylation of spermidine in polyamine catabolism. Biochimica et Biophysica Acta 633, 181-190. 
Seiler, N., Bolkenius, F. N. \& Sarhan, S. (1981). Formation of acetylpolyamines in the liver of fasting animals. International Journal of Biochemistry 13, 1205-1214.

Seiler, N., Sarhan, S., Grauffel, C., Jones, R., Knodgen, B. \& Moulinoux, J.-Ph. (1990). Endogenous and exogenous polyamines in support of tumour growth. Cancer Research 50, 5077-5083.

Smart, L. M., McLachlan, G., Wallace, H. M. \& Thompson, A. W. (1989). Influence of cyclosporin A and $\alpha$-difluoromethylornithine an inhibitor of polyamine biosynthesis, on two rodent $\mathrm{T}$-cell cancers in vivo. International Journal of Cancer 44, 1069-1073.

Stanek, J., Caravatti, G., Caprano, H., Furet, P., Mett, H., Schnieder, P. \& Regenass, U. (1993a). S-Adenosylmethionine decarboxylase inhibitors: new aryl and heteroaryl analogues of methylglyoxal bis(guanylhydrazone). Journal of Medicinal Chemistry 36, 46-54.

Stanek, J., Caravatti, G., Frei, J., Furet, P., Mett, H., Schneider, P. \& Regenass, U. (1993b). 4Amidinoindan-1-one 2'-amidinohydrazone: a new potent selective inhibitor of S-adenosylmethionine decarboxylase. Journal of Medicinal Chemistry 36, 2168-2171.

Tabor, C. W. (1968). Effect of temperature on the acetylation of spermidine. Biochemical and Biophysical Research Communications 30, 339-342.

Tabor, C. W. (1981). Mutants of saccharomyces cerevisiae deficient in polyamine biosynthesis: studies on the regulation of ornithine decarboxylase. Medical Biology 59, 272-278.

Tabor, C. W. \& Tabor, H. (1970). The complete conversion of spermidine to a peptide derivative in Escherichia coli. Biochemical and Biophysical Research Communications 41, 232-238.

Tabor, C. W. \& Tabor, H. (1985). Polyamines in microorganisms. Microbiological Reviews 49, 81-99.

Tofilon, P. J., Deen, D. F. \& Marton, L. J. (1983). $\alpha$-Difluoromethylornithine-induced polyamine depletion of 9L tumour cells modifies drug induced DNA cross link formation. Science 222, 1132-1135.

Wallace, H. M. (1987). Polyamine metabolism in mammalian cells: excretion and acetylation. Medical Science Research 15, 1437-1440.

Wallace, H. M. \& Coleman, C. S. (1990). Changes in polyamine acetylation in human cancer cells. Biochemical Society Transactions 18, 1091-1094.

Wallace, H. M. \& Keir, H. M. (1981). Uptake and excretion of polyamines from baby hamster kidney cells (BHK-21/C13). The effect of serum on confluent cell cultures. Biochimica et Biophysica Acta 676, $25-30$.

Wallace, H. M. \& Keir, H. M. (1986). Factors affecting polyamine excretion from mammalian cells in culture. FEBS Letters 194, 60-63.

Wallace, H. M., MacGowan, S. H. \& Keir, H. M. (1985). Polyamine metabolism in mammalian cells in culture. Biochemical Society Transactions 13, 329-330.

Wallace, H. M., Nuttall, M. E. \& Robinson, F. C. (1988). Acetylation of spermidine and methylglyoxal bis(guanylhydrazone) in baby hamster kidney cells (BHK-21/C13). Biochemical Journal 253, $223-227$.

Wallace, H. M. \& Quick, D. M. (1994). Regulation of spermidine/spermine $\mathrm{N}^{1}$-acetyltransferase in human tumour cells. Biochemical Society Transactions 22, 870-875. 